\title{
POSITIONING A UNIVERSITY FOR ENHANCED STUDENT PLACEMENT
}

\author{
by \\ PANOS APOSTOLIDIS, Ph. D. \\ Associate Professor of Marketing \\ University of Scranton \\ DEBORAH GOUGEON, Ph. D. \\ Assistant Professor of Statistics \\ University of Scranton \\ and \\ KYRIAKOS K. KIOULAFAS \\ Piraeus Graduate School of \\ Industrial Studies
}

\begin{abstract}
This article is a pilot study which discusses some of the recruitment issues and practices among universities and corporations focusing mainly on positioning, i.e., the adaptation of marketing communications to create a reputation for the college graduates in the job market, specifically toward groups of corporations. Attributes/criteria which a university holds can be turned into determining factors which the corporations will consider when evaluating an educational institution. Marketing a university can be beneficial to the development of its image and its competitive edge in the business world. By having the lines of communication between recruiters and the college placement office in good order, the graduating student can ultimately obtain the desirable job positions successfully.
\end{abstract}

\section{INTRODUCTION}

The title of the acclaimed book «What Color is Your Parachute?» might now be changed to the slogan «Your Parachute is not Colorful Enough as the Ti- 
mes Demand». Indeed, at a time when corporations recruit over dry martinis on the rocks, invite college graduates to dine in elegant restaurants, and offer boat trips with sightseeing, it seems that recruiting practices have changed a lot (Smith 1980).

Universities try to facilitate the placement of their graduates toward the companies and where the students prefer or want to go. Other schools strive to do better in quantitative terms by bringing in «large» numbers of recruiters and in qualitative terms by bringing in the «type» of corporations which are predicated to grow and survive in the years ahead. A successful match in recruitment, however, may require some systematic effort by the career and placement offices plus some strategic planning. In spite the fact that some recruiters visit the campuses with no real intention of recruiting, their success is largely attributed to how effectively and efficiently they work with the placement office (Hess, Swails, and Nogy 1980).

Research studies which have examined recruiting practices tend to suggest a need for the universities to respond and communicate more effectively with the big corporations in order to enhance the likelihood of successful job hunting and job posting for their graduates (Berry and George 1975 ; and Kotler and connor 1977).

This article is a pilot study which discusses some of the recruitment issues and practices among universities and corporations focusing mainly on positioning. The term positioning refers to the articulation of marketing communications to create a reputation for the university graduates in the job market, specifically toward groups of corporations. It means creating a strong identity and communicating it vividly to the market (Markin 1982). To establish such a market position the university should develop and communicate a unique image assembled through the elements of the marketing mix. This image represents a proxy for a set of attributes that are salient for determining recruiters patronage.

The development of a university's position will also require a measurement of recruiters perceived criteria to gauge its status and progress. Through evaluation, the university can reinforce its current image or to induce a change via programs, catalogs, or curricula. In the formulation of such a positioning the effect of involvement among the relevant parties can be deterministic (Arora 1982). Usually a measure of involvement is inferred from the degree of importance attached to various attributes/criteria a university holds.

The identification of determining factors which the corporations concider 
in college recruiting would obviously be a positive help in the positioning of an educational institution. As it has recently been pointed out, «the differences between business and the university are not as severe as some would believe ... because only recently have universities had to hustle for students the way business has long hustled for customers» (Berry and George 1975 ; and Kotler and Con nor 1977).

\section{THE DEMAND AND SUPPLY}

Official predictions indicate that employment opportunities will be higher for careers in computers, electronics, the energy sector, pollution control, and certain sciences where increased demand has already appeared. Service and leisure industries will also gain dramatically. Indeed, despite the moderate economic activity, most companies surveged in Northwestern University's Endicott Report said that their hiring needs for 1983 college graduates are up... [with]... a strong demand in accounting, business administration, computer science, sales, and marketing.

Corporations strive to discover and acquire ralented human beings to fulfill their managerial and operational needs, both immediate and for the future. They search for qualified college graduates and spend a considerable amount of time and money in recruiting. Many personnel executives today are educated in the behavioral sciences and have broad experiences beyond traditional labor relations. The AACSB has attempted to require that accredited schools include humanities courses and science courses as prerequisites to the business curriculum (Rehder 1982).

Correspondingly colleges and universities are preparing themselves to supply the necessary human resources which industry, government, and society are looking for. New curricula and programs are being designed, faculty members are being hired, libraries are being expanded, and old facilities are being renovated.

One of the goals of a university - beyond the mission of providing quality education and maintaining a reputable faculty - should be to provide challenging job opportunities and competent career development for graduates through encouraging and facilitating vigorous and successful recruitment by big and prosperous corporations. 
Effective recruiting today means the comparative selection of candidates to determine the most qualified. It further means an organized approach in judging both the reputation of universities and the personalities of graduates. Additional influences regarding the recruiting practices of corporations stem from forces such as the economy, competition, and new directives of management.

Corporations today want their employees to be educated, enthusiastic, motivated, and energetic with a high level of readiness. Managers seem to agree that what is lacking most in the college graduate is practical experience, self-discipline, career goals, maturity, imagination, and self-confidence (Steele 1981).

Figure I describes the complex task of college recruiting in the midst of en. vironmental forces, university goals, and the efforts of corporations.

\section{PURPOSE AND METHODOLOGY}

Recognizing the complexity of this task, the purpose of this study, as noted earlier, is to investigate the recruiting process among big corporations at fouryear colleges and universities in order to reveal which factors recruiters do consider when they select a university for recruiting purposes. Specifically, the study focuses on the following topics : (1) the determining factors which are used for selecting and visiting a university for recruiting purposes, (2) the importance (ranking) of these determinants, and (3) how (through what sources) a university is judged to qualify for the list.

After perusing the relevant literature, five personnel administrators were contacted to discuss their recruiting practices and were asked to designate factors/ variables they use when they select universities for recruiting. An array of factors consistently pertinent were included in a questionnaire. After the questionnaire was tested, more information on recruiting was added and demographic data for cross tabulations were requested.

Recruiters rated (on a scale) the relevance of the university's attributes in their choice for visiting the campus. The attributes/factors affecting recruiting are cited here below :

University has a well known academic reputation.

The location/distance of the university is relatively within recruiting practices. 


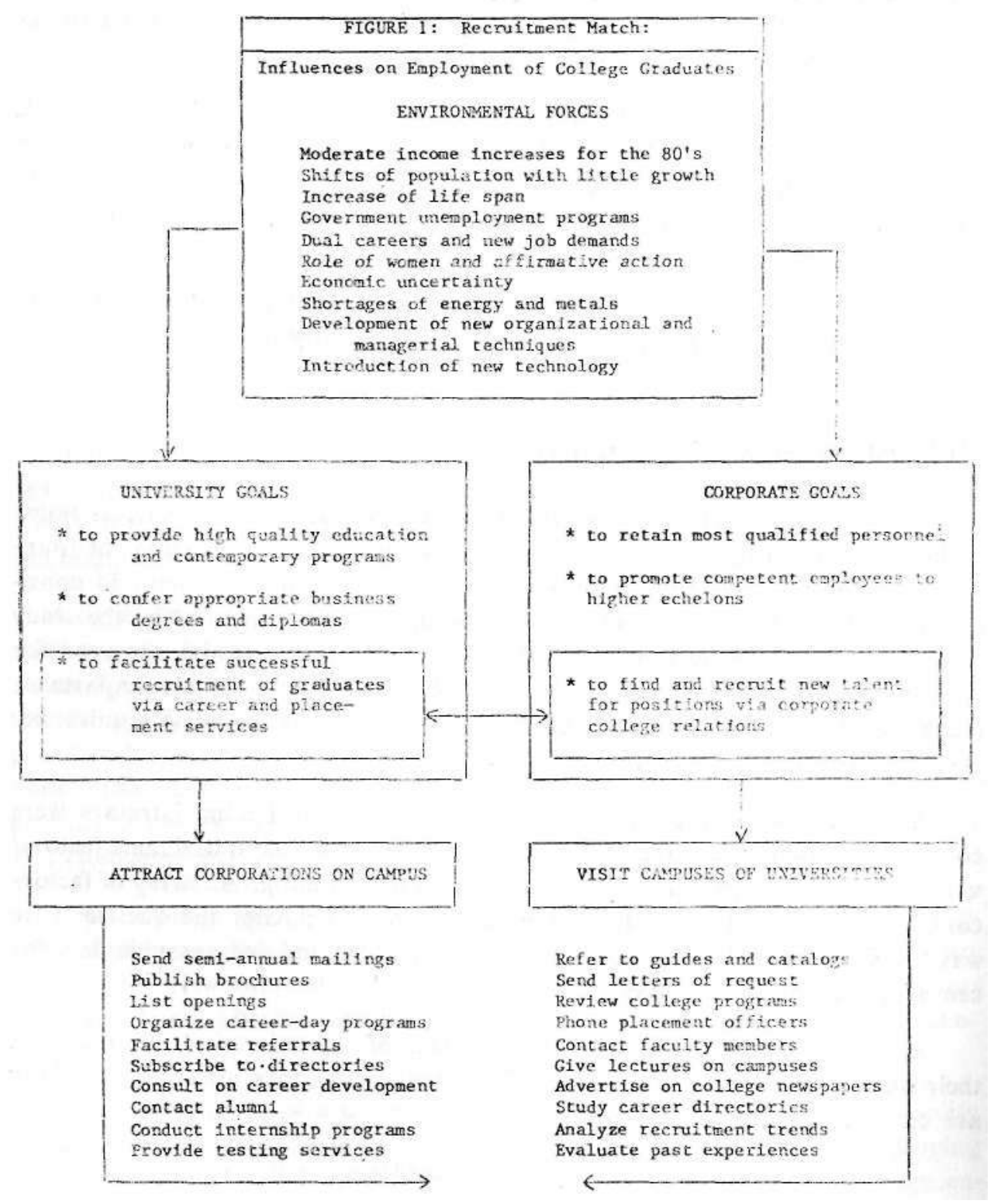


University is accredited by AACSB or other.

The professors of the university are well published.

The various programs offered by the university are updated.

The various degrees (BS, MS, Ph.D) offered by the university are well rounded.

The openings the corporation has for prospective graduates match.

The caliber/personality of the students attending there is high.

Top management specifies the universities to be visited by the recruiters.

Top management maintains a list which almost precludes other universities.

Demand and supply of employment indicates which universities should be visited.

Costs involved in recruiting are taken into account.

Matching specific needs of the corporation is important.

Other determining factors may be influential.

One hundred and nine corporations in the regions of the Mid-West, the Northeast, and the Atlantic were randomly selected to receive the final version of the questionnaire. These corporations represented various sizes and SICs From the Fortune 500 List, some 73 industrials were chosen plus 14 retailing. 5 diversified finance, 5 life insurance, 5 transportation, and 7 utilities.

Finally, fifty- six questionnaires out of the one hundred and nine corporations (a response of 51.4\%) were returned from such sectors as pharmaceutical, oil, automotive, machinery, food, publishing, and chemical. The rate of response has been found as satisfactory and the coverage of corporations is representative of the Fortune 500 group. Upon return of the questionnaire, a classification of factors took place. Ten factors were placed into one the following categories : school reputation, curriculum desigsn, managerial component, location, and other reasons.

An index was then constructed by calculating the ranking factors with numerical values as stated in Table 1. A summation which represents a weighted ave- 
rage of all the ranking frequencies of the responses provided a quantitative indication for each factor.

The recruiting factors were then tested to see if they were statistically significant on affecting the corporation's choice of a university. This test was perfor-

TABLE 1

FACTORS AFFECTING RECRUITING

RANKED BY DEGREE OF IMPORTANCE

\begin{tabular}{|c|c|c|c|c|c|}
\hline \multirow{2}{*}{$\begin{array}{l}\text { FACTORS AFFECTING } \\
\text { COLLEGE RECRUI- } \\
\text { TING }\end{array}$} & \multicolumn{5}{|c|}{ RANKING BY IMPORTANCE } \\
\hline & $1 \mathrm{st}$ & 2nd & $3 \mathrm{rd}$ & TOTAL & INDEX* \\
\hline $\begin{array}{l}\text { A. SCHOOL REPUTATI- } \\
\text { ON }\end{array}$ & & & & & \\
\hline 1. Academic Standing & 12 & 11 & 6 & 29 & 64 \\
\hline $\begin{array}{l}\text { 2. Accreditation } \\
\text { 3. Professorship Quali- }\end{array}$ & 10 & 5 & 3 & 18 & 43 \\
\hline ty & 6 & 5 & 9 & 20 & 37 \\
\hline Total & 28 & 21 & 18 & 67 & 144 \\
\hline $\begin{array}{l}\text { B. CURRICULUM DE- } \\
\text { SIGN }\end{array}$ & & & & & \\
\hline $\begin{array}{l}\text { 4. Programs Offered } \\
\text { 5. Degree Specializati- }\end{array}$ & 6 & 6 & 1 & 13 & 31 \\
\hline ons & 4 & 4 & 5 & 13 & 25 \\
\hline $\begin{array}{l}\text { Total } \\
\text { C. MANAGERIAL COM- } \\
\text { PONENT }\end{array}$ & 10 & 10 & 6 & 26 & 56 \\
\hline 6. Predetermined List & 2 & 3 & 0 & 5 & 12 \\
\hline $\begin{array}{l}\text { 7. Corporate Needs } \\
\text { 8. Management Directi- }\end{array}$ & 1 & 1 & 2 & 4 & 7 \\
\hline ves & 0 & 1 & 1 & 2 & 3 \\
\hline Total & 3 & 5 & 3 & 11 & 22 \\
\hline D. LOCATION & & & & & \\
\hline 9. School Proximity & 2 & 3 & 2 & 7 & 14 \\
\hline Total & 2 & 3 & 2 & 7 & 14 \\
\hline $\begin{array}{l}\text { E. OTHER REASONS } \\
\text { 10. Student Personality }\end{array}$ & 0 & 1 & 1 & 2 & 3 \\
\hline Total & 0 & 1 & 1 & 2 & 3 \\
\hline $\begin{array}{l}\text { TOTAL FREQUEN- } \\
\text { CY }\end{array}$ & 43 & 40 & 30 & 113 & \\
\hline
\end{tabular}

* The total number of responses was 56 . 
med using the chi-square analysis procedure and the results can be seen in Table 2. The null hypothesis $\left(\mathrm{H}_{0}\right)$ was that these factors are of equal importance. The decision rule was to reject $\mathrm{H}_{0}$ if the computed chi-square statistic is greater than the critical chi - square, with eight degrees of freedom and the $\mathrm{X}-.05$ level of significance. The null hypothesis is employed, of course, to generate the expected frequencies in the calculation of the chi-square statistic ${ }^{1}$.

TABLE 2

\section{TESTING THE RELATIVE IMPORTANCE OF FACTORS AFFECTING RECRUITING}

(Observed Values vs. Expected Values)

\begin{tabular}{|c|c|c|c|c|}
\hline $\begin{array}{c}\text { Factors Affecting Recruiting } \\
\text { at a Particular University }\end{array}$ & $1 \mathrm{st}$ & $\begin{array}{l}\text { Ranking } \\
\text { 2nd }\end{array}$ & $3 \mathrm{rd}$ & Totals \\
\hline $\begin{array}{l}\text { A. School Reputation } \\
\text { B. Curriculum Design } \\
\text { C. ManagerialComponent } \\
\text { D. Location } \\
\text { E. Other Reasons }\end{array}$ & $\begin{array}{l}28 / 25.49 \\
10 / 9.89 \\
3 / 4.19 \\
2 / 2.66 \\
0 / \quad .76\end{array}$ & $\begin{array}{r}21 / 23.72 \\
10 / 9.20 \\
5 / 3.89 \\
3 / 2.48 \\
1 / \quad .71\end{array}$ & $\begin{array}{r}18 / 17.79 \\
6 / 6.90 \\
3 / 2.92 \\
2 / 1.86 \\
1 / \quad .53\end{array}$ & $\begin{array}{r}67 \\
26 \\
11 \\
7 \\
2\end{array}$ \\
\hline Total & 43 & 40 & 30 & 113 \\
\hline
\end{tabular}

\section{ANALYSIS AND DISCUSSION}

Out of several factors which have been presented for evaluation and screening, the following groups were given distinctive consideration :

1. Note that the small expected frequencies suggest that the $X^{2}$ test be used with extreme caution. The calculated $\mathrm{X}^{2}$ value is :

$$
\mathrm{X}^{2}=\frac{(28-25.49)^{2}}{25.49}+\frac{(10-9.99)^{2}}{9.89}+\ldots=2.9853
$$

The critical $\mathrm{X}^{2}$ value with $(\mathrm{r}-1)(\mathrm{c}-1)=8$ degrees of freedom at the .05 level of significance is 15.507, thus 2.9853 ( 15.507 , therefore accept $\mathrm{H}_{0}$. In essence, the various factors/variables used in selecting a university for recruitment purposes were found of no significance. 
The reputation of the university, as reflected in academic recognition, quality of faculty, and accreditation appeared to be prime causation factors for interviewing at a particular university. Most of the top ten universities (Harvard, MIT, Stanford) were reportedly mentioned by the corporations in the sample.

The number and variety of programs offered by a university, the degree offered, and the curriculum design were highly rated as good reasons for selecting the particular university.

Market forces as they are reflected in demand and supply for college talent matching the specific needs of the corporations, recruitment of minority groups, and the available job openings in the corporations were cited as affecting the choice of corporations to recruit or not to recruit at a particular university.

Future projections suggest that perhaps shortages in employment may force corporations to visit more colleges or to resort to less prestigious schools in order to obtain the required human resources ; thus more emphasis may then be placed on the factors in this category.

Administrative reasons for recruitment include top management designations and predetermined lists, depending upon the division in which the prospective student would be employed.

It was noted that economic factors have some influence in the selection process, in particular, the distance of the school in relation to the location of the corporation which reflects per diem travel. Locality fosters ease, familiarity and convenience in recruitment with possible community involvement and perhaps better salary agreements.

The personality and caliber of graduates and the past experience of corporations recruiting at a particular school (number of successes) were rated quite low by the sample when the factors were ranked in preference. When mentioned as determining factors, however, they were enumerated twenty seven times, thus illustrating that they are perhaps crucial elements to consider in recruiting. The requirement of the «job and personality» of the company has been emphasized elsewhere (Bauman 1982). The rejection often occurs when the student seems to lack a basic knowledge about the company (Hess, Swails, and Nagy 1980).

Based on empirical results we find very weak support for differentiating among the various variables. Only the relative strength of the reputation of a university can be emphasized. To succeed in the job market, a university must create an image that not only takes into consideration its own strengths and weaknesses, 
but differentiates them against those of its competitors. The elements needed to build an image must all be thought of as a multivariate marix.

\section{CONCLUSION AND IMPLICATIONS}

Marketing a university can be instrumental in the development of its image and its competitive advantage in the business world.

A university which desires to establish a superior reputation must constantly evaluate itself. Do we have faculty of quality? Do we offer courses that meet the needs of the corporate world? Are these courses taught at a level reflecting true competence in the economy and society? This evaluation is more relevant if judged by the business community.

Once the university is convinced of its ability to turn out superior graduates, it should then consider marketing this with confidence. The marketing could be undertaken by direct communication exposure to the corporations since they ultimately hire the students. The college could learn from corporations which have hired past graduates as to what they perceive the strong and weak points. Alterations in the programs, methods and course curricula could then be made based on their findings.

Reputation and image appear to be strong in perceptual reference among the recruiters. Other variables are not equally significant. Some differentiation is practiced among the universities. In such differentiated marketing the slogans «The Forest of Scholars.» «The Depot of Engineers,» «A Place for Intellectuals,» are generally appealing. The truth is however that a university should be concerned with the end product of education. Part of this is a well- rounded graduate who can easily become the «qualified» human resource in large corporations.

Between doing nothing and hard-sell approaches, a university can practice a «professional type of marketing» appropriate for the goal of recruiting. A systematic marketing effort, along with organized means for filing and monitoring data, can easily provide a basis for responding to the recruiting needs of the business community (Surface 1971).

Such efforts may call for establishing a center of responsibility ; for planning 
and delivering a communication system ; for setting a special budget and recogni zing results in the recruiting/placement activity.

We recommend further study based on measurement of additional variables, the inclusion of a greater number of corporations from other geographical areas and an extension of the research toward different companies and industries.

\section{REFERENCES}

Arora, Raj (1982), «Consumer Involvement in Store Positioning,» Journal of the Academy of Marketing Science, (Winter, Spring 1982), 109-24.

Bauman, Martin H. (1982), «What You Can and Can't Learn from Interviews,» Wall Street Journal, (August 16,1982), 12.

Berry, Leonard and George, William, «Marketing the University», Atlantic Economic Review (July-August 1975), 4-8.

College Placement Council Report No. 3, (July 1981), and Recruiting Trends, Enterprise Publications, July 1981

Fein, Richard (1982), «Building a Strong Recruiting Program», Journal of College Placement, (Spring 1982), 23.

Goodman, Steven E. (1982), «SMR Forum: Does the Business Student Have a Stake in U.S. Businessc» Sloan Management Review, (Winter, 1982), 77-78.

Hess, H. Richard, Richard Swails, and Daniel R. Nagy (1980), «Colleges get Feedback on OnCampus Recruiting Process,» Journal of College Placement, (Fall 1980), 27-29.

Kotler. Philip and Richard Connor, Jr. (1977), «Marketing Professional Services», Journal of Marketing (January 1977)., 71-76.

Maggard, John B. (1976), «Positioning Revisited», Journal of Marketing, (January 1976), 63 - 66. Markin, Rom (1982), Marketing (New York : John Wiley and Sons), 116.

Rehder, Robert R. (1982), «SMR Forum : American Business Education - Is It Too Late To Changée» Sloan Management Review, (Winter 1982), 63.

Smith, Ann Mackay (1980), «Recruiting Top MBAs Can Begin with a Dry Martini on the Rocks,» Wall Street Journal, September 25,1980,1. 
Steele, E. W. (1981), «What Recruiters Should Look for in Applicants», Journal of College Placement, (Spring 1981), 57-58.

Surface, James (1971), «Universities Aren't Corporations», Business Horizons, (June 1971), 75 80.

Trout, Jack and Al Ries (1972), «The Positioning Era Cometh,» Advertising Age.

Whalen, Bernard F. (1979), «Marketer Designs Permanent Media to Position Firms,» Marketing News, (November 2, 1979), 1. 